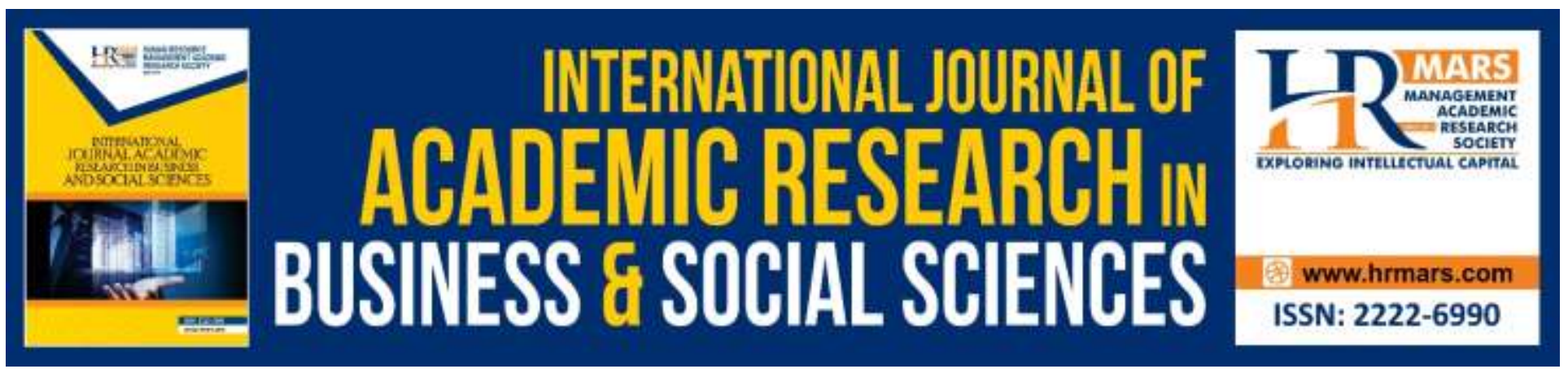

\title{
A Shariah Perspective Review on Single Stock Futures
}

Mahmud Jamaludin \& Nadhirah Nordin

To Link this Article: http://dx.doi.org/10.6007/IJARBSS/v10-i5/7213

DOI:10.6007/IJARBSS/v10-i5/7213

Received: 09 March 2020, Revised: 10 April 2020, Accepted: 25 April 2020

Published Online: 19 May 2020

In-Text Citation: (Jamaludin \& Nordin, 2020)

To Cite this Article: Jamaludin, M., \& Nordin, N. (2020). A Shariah Perspective Review on Single Stock Futures. International Journal of Academic Research in Business and Social Sciences, 10(5), 415-425.

Copyright: (C) 2020 The Author(s)

Published by Human Resource Management Academic Research Society (www.hrmars.com)

This article is published under the Creative Commons Attribution (CC BY 4.0) license. Anyone may reproduce, distribute, translate and create derivative works of this article (for both commercial and non-commercial purposes), subject to full attribution to the original publication and authors. The full terms of this license may be seen

at: http://creativecommons.org/licences/by/4.0/legalcode

\section{Vol. 10, No. 5, 2020, Pg. 415 - 425}

Full Terms \& Conditions of access and use can be found at http://hrmars.com/index.php/pages/detail/publication-ethics 


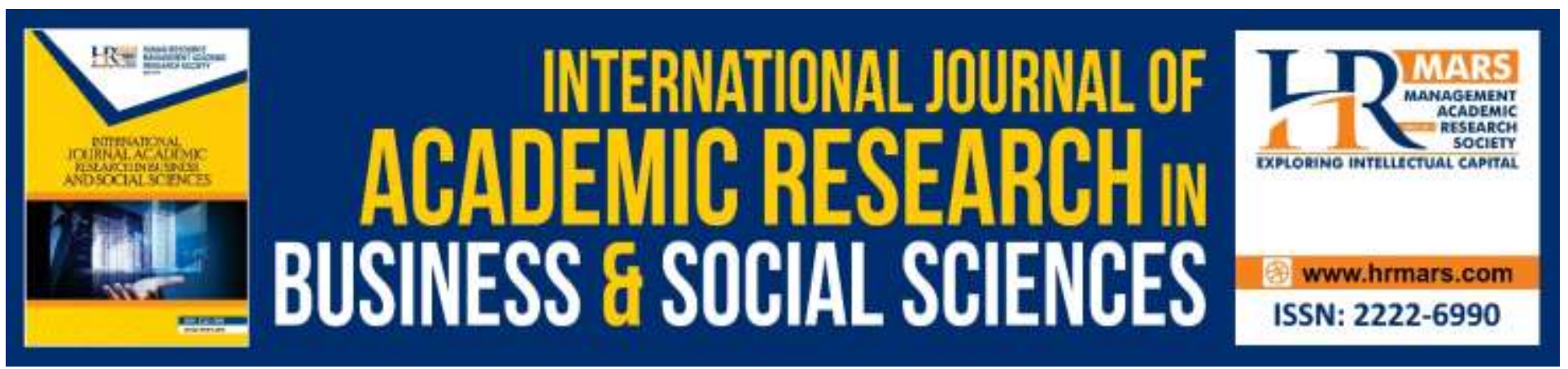

\title{
A Shariah Perspective Review on Single Stock Futures
}

\author{
Mahmud Jamaludin \& Nadhirah Nordin \\ Faculty of Islamic Contemporary Studies, Universiti Sultan Zainal Abidin, Gong Badak Campus, Kuala \\ Terengganu, Terengganu Darul Iman.
}

\begin{abstract}
Single Stock Futures (SSFs) are referring to the contracts between seller and buyer and these two investors need to perform their responsibilities towards the promised contract in the predetermined future, which is on the maturity date with the agreed price and quantity. This is one of the derivative contracts that is produced from the massive development of the conventional financial engineering that is purposely used for protecting the value in the financial market. However, the Muslim scholars put different overviews in determining the Islamic ruling on this above-mentioned contract. Part of them are accepting this form of contract due to its ability in protecting and securing the value and some of them refuting it. The reasons of accepting and rejecting are outwardly different as well. This situation arises the questions pertaining the status of this contract before the Islamic legislative ruling. Hence this research will be analysing the SSFs in according to the perspective of shariah (Islamic law). This qualitative research opted the exploratory design and obtained the data through the document analysis. The result shows that this contract is bringing few of shariah's issues such as gharar, speculation and gambling that implicate the laws of applying this SSFs in the Islamic financial institution.
\end{abstract}

Keywords: Derivative Contract, Future Stocks, Single Stocks, Shariah.

\section{Introduction}

Contract of Single Stock Futures (SSFs) is one of the derivative financial instrument in the form of future contracts that is categorized as an instrument that protecting the value since 1970s as the market entered a downturn graph and the prices of commodity such as oil, sugar, coffee, cotton, currency, bon, stocks and sundries became fluctuated (Kamali, 2002). In consequence, the traders and investors started to manage the risk of price changes by readily putting down a fix price of the commodity value even the submission of the respective goods are set in the future. Conceptually, this contract is regarded as an additional financial instrument towards the opted underlying stock portfolio in the Malaysia financial market that prepares the channel for protecting the value from the stock's exposure towards the price changes.

The ability to lock the buying price or the selling price of underlying assets in the future able to put the participants of the market to be at ease and secured from any undetermined price that probably happen in the future. Other than that, it makes the value protection and the efficiency of the 
INTERNATIONAL JOURNAL OF ACADEMIC RESEARCH IN BUSINESS AND SOCIAL SCIENCES Vol. 10, No. 5, May, 2020, E-ISSN: 2222-6990 @ 2020 HRMARS

investment plan be at convenience state. Market price protection that earn the development of revenue by the requirement of managing the risk is serving the best role in giving the efficient management towards the market risk and the return of investment risk (Bakar, 2008).

Besides, al-Aminie (2008) stated that Islamic Fiqh Academy also agreeing on the benefit or the public interest that can be achieved in the transaction of future trading contract such as open the chances for the industry of institutions and commercial to run and financing their projects through publications, stock sales, financial instrument and preparing the accommodation for the traders to execute their transactions in the commercial and commodity instruments. However, this consideration is clearly attached to the illegal transaction according to shariah, such as gambling, exploitation and taking the unlawful properties. Hence, this article is identifying and making analyses on the concept and specification of the SSFSs trading contract based on the perspective of shariah.

\section{Concept and Specification of Single Stock Futures (SSFs) Contract}

Future trading contract is referring as a contract between sellers and buyers that have to execute their roles and responsibilities in the predetermined future, which is on the its mature date (Ali, 2006). SSFs contract is a business activity that manages the future market upon the specific stocks of individuals that are on the list of SSFs trading only (Bursa Malaysia, 2020).

Amongst the general idea of SSFs contract is the availability of uniform contract specification that is endorsed for trading purposes by Malaysia Stock Exchange, standard quality for underlying asset of each SSFs is equivalent to 1,000 unit stocks and the expire date for the future trading is determined earlier which is on the last day of transaction on that respective month of contract by using the cash settlement (Bursa Malaysia, 2019). The following table indicates the contract specification that was published on $13^{\text {th }}$ January 2020 :

\begin{tabular}{|l|l|}
\hline Contract Code & \multicolumn{1}{|c|}{ SSF } \\
\hline Underlying Instrument & Selected single stocks \\
\hline Contract Size & 1,000 -unit shares \\
\hline Minimum Price Fluctuation & 0.02 point valued at RM20.00 \\
\hline Daily Price Limits & None \\
\hline Contract Months & $\begin{array}{l}\text { Sport month, the next month and the next two calendar quarterly } \\
\text { months. The calendar quarterly months are March, June, September and } \\
\text { December. }\end{array}$ \\
\hline Trading Hours & $\begin{array}{l}\text { First trading session: } \\
\text { Malaysian 08:45a.m.to 12:45p.m. (GMT+8) } \\
\text { Second trading session: } \\
\text { Malaysian 2:30p.m. - 5:15p.m. (GMT+8) }\end{array}$ \\
\hline Final Trading Day & The last business day of the contract month \\
\hline Final Settlement & Cash settlement based on the final settlement value \\
\hline Final Settlement Value & $\begin{array}{l}\text { The final settlement value shall be the weighted average price, rounded } \\
\text { to 2 decimal points, or in the event the final settlement value is } \\
\text { equidistant between 2 minimum price fluctuation of the underlying share } \\
\text { prices traded for the morning and afternoon trading session on Bursa } \\
\text { Malaysia on the Final Trading Day. }\end{array}$ \\
\hline Speculative Position Limit & $\begin{array}{l}\text { Maximum number of net long of net short positions to be held: } \\
1,350 \text { contract, or 2,300 contract (If Average Daily Trading Volume (ADTV) } \\
\text { of the underlying stock is more than 20 million for the most recent six- } \\
\text { month period) }\end{array}$ \\
\hline
\end{tabular}


INTERNATIONAL JOURNAL OF ACADEMIC RESEARCH IN BUSINESS AND SOCIAL SCIENCES Vol. 10, No. 5, May, 2020, E-ISSN: 2222-6990 @ 2020 HRMARS

For example, when any individual is doing a transaction of buying or selling one of the SSFs contracts, it is equivalent to buy or sell 1,000 stock units that is set as an underlying asset for that contract. The price of SSFs contract for the delivery and final settlement in the future maturity date is upon the agreement of both investors during the process of selling or buying the SSFs contract. However, an individual may close-out the SSFs contract (either bought or sold) in any time before reaching period of contract maturity date (Suruhanjaya Sekuriti, 2018). There are few foundational elements in the operation of SSFs contract; underlying assets, market participants, transaction venue and position during transaction process.

\section{First Foundation: Underlying Assets}

There are three classifications of underlying asset for the purpose of transaction based on derivative contract in Bursa Malaysia Derivative Berhad (BMD); (1) commodity underlying asset, (2) equity underlying asset, and (3) and financial underlying asset (Bursa Malaysia, 2019). Underlying asset of SFSs is a type of equity which comprises stock and stock index. Bursa Malaysia has listed 10 types of underlying assets that have been chosen for receiving offer to trade via SSFs contract since April 2006. On the following 2019, only the remaining 7 underlying stocks were still being offered for trading (Sang, 2019). Currently, started from $16^{\text {th }}$ January 2020, new lists have been issued out by Bursa Malaysia, which stated 10 of the chosen SSFs trading as follows:

\begin{tabular}{|c|l|c|c|}
\hline No. & \multicolumn{1}{|c|}{ Underlying SSFs Stock } & Code SSF & Preliminary Margin (MYR) \\
\hline $\mathbf{1}$ & CIMB Group Holding Bhd & FCIM & 250 \\
\hline $\mathbf{2}$ & DRB-HICOM Bhd & FDRB & 100 \\
\hline $\mathbf{3}$ & Gamuda Bhd & FGAM & 200 \\
\hline $\mathbf{4}$ & Genting Bhd & FGEN & 300 \\
\hline $\mathbf{5}$ & Genting Malaysia Bhd & FGEM & 150 \\
\hline $\mathbf{6}$ & Hartalega Holding Bhd & FHAR & 250 \\
\hline $\mathbf{7}$ & Inari Amertron Bhd & FINA & 100 \\
\hline $\mathbf{8}$ & My EG Service Bhd & FMEG & 100 \\
\hline $\mathbf{9}$ & Telekom Malaysia Bhd & FTEL & 200 \\
\hline $\mathbf{1 0}$ & Top Glove Bhd & FTOP & 200 \\
\hline
\end{tabular}

*Reference: http://www.bursamarketplace.com/ssf/bm.html\#what-is-ssf

\section{Second Foundation: Market Participants}

Market participant is classified into three major groups which are the hedgers, speculators and arbitrageurs (Suruhanjaya Sekuriti, 2005). These participants are from the individuals, finance institutions, insurance company, bond portfolio manager, asset manager, employer provident fund, company treasurer, and local members of exchange stock (Nordin, 2014).

\section{a) Hedger}

Hedger is among a main participant in market that use SFSs as one of the medium to manage the risk - to secure the unstable and fluctuate value. There are two types of identified hedger which is the value protector and securing the current market position or called as portfolio hedging (Suruhanjaya Sekuriti, 2005). For the purpose of securing the value, the traders or investors will sit on the expecting position as a replacement for a current value. For instance, John is interested to have 1,000-unit stocks from Telekom Malaysia Berhad in upcoming month by practicing SFSs transactions. This 
situation may secure and control the value that need to be paid by John when reaching the maturity point cum able to secure from the increasement of stock price in the future.

However, the portfolio hedging is referring to the involvement of institution that is possessing or holding the major or various stock portfolio which frequently similar to the whole market prestation (Suruhanjaya Sekuriti, 2005). Hence, the SFSs able to become an efficient hedger for that portfolio, hence security from the declination of price is presentable. For example, the holder of Bursa Malaysia Berhad holder participates in market of SFSs in order to avoid from the risk of future declination of market price. Thus, they can control or minimize the risk level that probably entailed from that drop off in the future.

\section{b) Speculator}

The speculator is performing its important role in any of SFSs by preparing trading volume and liquidity by taking over the risk that hedger attempts to avert (Sekuriti, 2005). This group of speculators is participating in the market world solely to gain profit by taking the risk that is being avoided by the hedgers. The aim of them to take the risk is not secure the value but they believe that presence of profit behind those risks. Their participation helps to increase the liquidity in derivative market, such as in this SFSs.

For example, the price of FGEN JUN06 is currently on trading at RM22.80. The speculators assume that it will be increased in a short period of time and decide to buy the FGEN JUN06 contract which is equivalent to 1,000 Genting Bhd. Stock. If the future trading broker set a preliminary margin (mortgage) at RM1,250 for each contract, these amounts will be debited from the trading participant accounts, hence deposited to the trust account of the brokers - with the assumption of GEN JUN06 contract will be increased to a higher points until reaching RM24.80. When the speculators assured that the value reached at the peak, thus the decision will be taken to close out the position point by selling 1 contract of GEN JUN06 for sealing its former point. The earlier margin will be returned with the attachment of the difference basic value stock, which is 1,000 stocks $\times($ RM24.80-RM22.80) $=$ $\mathrm{RM} 2,000.00$. The capital increases to $\mathrm{RM} 3,250$ from $\mathrm{RM} 1,250$, return profit $160 \%$ within the period of the value stock only could be increased to $8.8 \%$.

\section{c) Arbitrageur}

Arbitrageurs are participants that involve in the future trading market solely to get the profits from the differences of price that crossing the various markets or trading maturity date (Suruhanjaya Sekuriti, 2005). Those arbitrageurs will buy the future trading contract at a lower price market and re-sell it at a higher value. Usually, it is a short span process and the level of balancing could be preserved in all markets. The presence of arbitrageurs in derivative market increases the liquidity level and productivity in markets.

\section{Third Foundation: Transaction Venue}

In general, the transaction business based on the derivative contract consists of future contract, future trading, options and swaps that can be conducted in two different venues, which is in the exchange traded and at the counters (Tahir and Ahmad, 2009). However, for the future trading contract, it only can be conducted in stock exchange, including the SFSs that is traded in Bursa Derivatif Malaysia Berhad (BMDB) which gathers the sellers and buyers with the decided price set by the third party which is the exchange trade (Hull, 2003). 
INTERNATIONAL JOURNAL OF ACADEMIC RESEARCH IN BUSINESS AND SOCIAL SCIENCES Vol. 10, No. 5, May, 2020, E-ISSN: 2222-6990 @ 2020 HRMARS

\section{Forth Foundation: Position During Transaction}

The position during conducting transaction of SSFs contract can be divided into two main forms, which is short and long positions. The short situation is referring to the market participants that sold the future trading contract and prepare to do submission or delivery. The long position is a situation that depicts the market participants that bought the future trading contract and ready to receive the delivery (Sekuriti, 2005). With the position of long, the participants can buy any asset in the future with the determined current price. Meanwhile, the short position means that the participants able to sell in the future with the determined current price. In this sense, regardless of the cash market value during the submission time, the party that choose long position is responsible to buy and the short party need to sell despite of getting loss upon reaching the contract date of maturity.

For instance, if participant $A$ is on the position of long with the price of RM30 and the price market at that particular date is RM25, he or she needs to buy it at RM30. This situation signifies that participant A will lose RM5. On contrary, if the market price at that time is RM35, it will incur a loss for short party. Both of these positions happen in the derivative contract in all types of contract despite of the different in how the transaction is conducted (Nordin, 2014).

\section{Issues of Syariah in Single Stock Futures Conventional Contract}

The opinion of scholars appears to be various pertaining to the permissibility of applying SSFs from the perspective shariah. Some of them are totally refuting and the rest are accepting SSFs solely for the purpose of securing the value (Nordin, 2014). In reference to the stances of the scholars on the permissibility of applying future trading contract, it can give a clear Islamic perspective on SSFs that is traded in Bursa Derivatif Malaysia Berhad. A detail research on the contract specification identified that there are few shariah issues as follows:

\section{First Issue: Gharar}

Sekuriti (2006) defines gharar as uncertain elements that can expose someone to danger. In the context of transaction, if any agreement that has such element, hence it indicates that this kind of transaction attached to gharar, means it has the presence of uncertain element such as the unstated price during transaction. Al-Saati, 2003; Obaidullah, 1998; and Khan, 2008 have scholarly mention the interrelation of the issue gharar in the future trading contract.

Sekuriti (2006) through its Shariah Advisory Council relates the issue of gharar in the SFSs trading contract from the aspect of sighah (formal exchange between the contractual parties) and aqad (agreement) subject. From the aspect of sighah aqad, there is ta'jil badalayn that entails the debt sales with debt (bay' al-dayn bil al-dayn) and the allowed close-out mechanism invites the selling before qabd happens. Meanwhile from the aspect of aqad subject, it presents the issue of bay' $m a^{\prime} d u m$ which means the absence of items or payment during the agreement of contract is been done.

The issue of ta'jil badalayn happens when the contract is agreed between the involved parties without the presence of payment and items (subject of aqad). According to Resolusi Akademi Fiqh al-Islami (1992), this situation can create ambiguous submission and capability of each parties in fulfilling their responsibilities, respectively. This statement is also agreed by AAOIFI Shariah Advisory Council (2010). However, Abu Bakar (2014) stated that Akademi Fiqh al-Islami decided that salam contract is allowed during future trading contract. Other than that, Haron (2001) concluded that issue of $t a^{\prime} j i l$ badalayn during transaction that is related to stocks is not permissible according to shara' 
INTERNATIONAL JOURNAL OF ACADEMIC RESEARCH IN BUSINESS AND SOCIAL SCIENCES Vol. 10, No. 5, May, 2020, E-ISSN: 2222-6990 @ 2020 HRMARS

since the purchase transaction happens with debt (bay' al-dayn bi al-dayn). Moreover, Syathnawi (2009) highlighted the presence of the agreed religious consensus stated on the forbidden of bay' $a$ dayn bi al-dayn.

Nonetheless, Kamali (2002) gave his opinion that the ambiguity element that is related to stock exchange is only happens when there is no control and unorganized transaction. Meanwhile the forbidden element during bay' al-dayn bi al-dayn can be overcome with the principles of $w a^{\prime} d$ or $w a^{\prime}$ dan in the Islamic finance. In reference to this opinion, the ambiguity issue in the aspect of receiving items and payment in SSFs is no longer exist since the future trading contract that is traded in Malaysia is currently managed by Bursa Malaysia Berhad (BMDB) which is controlled by Securities Commission Malaysia.

Other than that, the issue of gharar that is related to the permissibility to close out contract by settling the cash payment before reaching the maturity date or item submission or exchange of ownership, depicts that the selling activity is yet to happen (no qabd). Suruhanjaya Sekuriti (2006) defined that qabd according to fuqaha (Muslim legal scholars) as the domination or ownership towards something is usually referring to certain uqud mu'awadat (exchange agreement. Syathnawi (2009) stated that the majority of Muslim scholars forbid the purchase transaction before qabd.

Sekuriti (2006) has highlighted two types of qabd in the perspective of Islam, which are qabd haqiqi or hissi and qabd hukmi or maknawi. Qabd haqiqi is a qabd that is manifestly happens when the buyer takes the sold items. Meanwhile, qabd hukmi is referring to the qabd that is not clearly manifested during transaction. Kamali (2000) and al-Amine (2008) stated that qabd hukmi happened during trading in stock exchange, such as in future trading contract due the presence of documents that are guaranteeing the ownership transference from both sellers and buyers after the contract being registered by Bursa Malaysia Derivative Clearing which hold a role in matches the similar needs of these two parties and records the responsibilities of the parties that are subjected to agreed contract and the required payment. However, the presence of close-out mechanism before reaching maturity date causes the presence of speculative activities.

Meanwhile, the issue of gharar in the aspect of aqad's subject means the presence of $b a y^{\prime}$ ma'dum $^{\prime}$ which is the items under contract are not presentable during the agreement and unable to clarify their existence. Al-Zuhayli (1997) stated that majority of fuqaha Hanafi, Shafi'i and Maliki agree upon the requirement to present the purchase item during agreeing the contract. Besides, Nor Fahimah (2014) concluded that the majority of fuqaha agreed that the absence of asset at that point of time will entail the ineligibility of contract due to the presence of gharar element. This situation also being supported by al-Darir (1993), F. Khan (1995) and al-Khafif (1996) that forbad the usage of contract due to the issue of $m a^{\prime} d u m$.

In contrary, Obaidullah (1998); Bakar (1998); Kamali (2002) and Suruhanjaya Sekuriti (2006) through its shariah advisory council refute the view that forbid the derivative contract, including SSFs contract by depending on the absence of items during contract. Amongst their arguments are citing the view of Ibn Qayyim that refuted the non-exist contract subject is forbidden. Ibn Qayyim (1993) asserted that the real reason of putting the forbidden of $m a^{\prime} d u m$ is due to the presence of inability to deliver the sold items. Hence, the exist item and able to be received and created is generally allowed in this transaction. 
INTERNATIONAL JOURNAL OF ACADEMIC RESEARCH IN BUSINESS AND SOCIAL SCIENCES Vol. 10, No. 5, May, 2020, E-ISSN: 2222-6990 @ 2020 HRMARS

\section{Second Issue: Speculation}

Kamus Dewan Bahasa dan Pustaka (2020) defines the meaning of speculation as trading in commodities, stock, etc in the hope of huge profit but need to shoulder a huge risk as well. For instance, in the world of stock transaction, the investor buys a stock during its low price and sell it whenever the price increases. Naughton (2000) and Ramli (2000) stated that the speculation is referring to the action that aims to get the profit within a short period of time during the fluctuating prices, without any intention to participate in that contract. The opinion of the fuqaha agreed that there is certainly the existence of speculation element in the derivative contract when there is no intention to physically receive or deliver the items and only interested to the price changes when close out the contract before its maturity period.

Usmani (1999): Chapra (1988); Khan (2008); Khan (1997); Obaidullah (2001); al-Misri (2007) and alSaati (2002) stated there is element of speculation in future trading contract when there is no intention to accept or deliver the item physically. Both of the parties only interested with the price changes when close out the contract before maturity period and most of its contract is not involving the submission of the item. In the trading contract of SSFs, the market participants able to close out the contract any time before reaching its maturity date. This situation is exposing the speculative activity clearly and openly in this contract-based transaction.

The mechanism of close-out exposes the market to the participation of speculators that only interested to join the market solely to gain the profit from the inconsistency of price. The prohibition on the derivative contract is clearly set by the scholars due to the existence of speculative issue that is almost similar to gambling which is forbidden in Islam. Hence, Usmani (1999) asserted that all future contracts and future trading regardless of their underlying assets are forbidden in Islam because most the related contracts are not involving item submission or ownership and solely to gain the profit from the inconsistency of prices.

\section{Third Issue: Gambling}

Gamble or in Arabic language called as qimar or maysir means any activities that involve betting, which is the winning party will take all the waged items meanwhile the loser will receive the vice versa fate (Suruhanjaya Sekuriti, 2006). The prohibition to practice gamble is clearly indicated in Quran as follow:

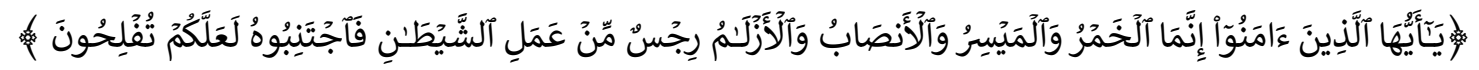

O you who have believed, indeed, intoxicants, gambling, [sacrificing on] stone alters [to other than Allah], and divining arrows are but defilement from the work of Satan, so avoid it that you may be successful.

(al-Maidah, 5:90)

Engku Ali (2010) stated that gambling may happen in derivative contract that involves close-out contract practice before maturity date and trading based on margin. Besides, Bakar (1998) stated that the condition of requiring amount of deposit as a margin payment before start the trading transaction is considered as one of the gambling activities that is prohibited in Islam. In SSFs contract, the margin payment is required in any offered contract for trading. As an example, Genting Bhd. June 2006 SSFs, that has reference code FGEN JUN06 - if it were traded at RM22.80 and the investors assume it will be increasing within a short period of time, hence the investors will decide to buy 1 contract of FGEN JUN06 which equivalent to 1,000 Genting Bhd. stocks. Hence the future trading 
brokers will set a preliminary margin (a form of mortgage) of RM1,250 for each contract; this contract will be debited rom the investor trading account and will be kept in trust by brokers. Whenever the increasement of price happens before the contract maturity date with the assumption of reaching up to RM24.80, the investor decides to close out the former position before reaching its maturity date. Preliminary margin will be returned with the difference value of basic stock, which is 1,000 stocks $x$ $(\mathrm{RM} 24.80-\mathrm{RM} 22.80)=\mathrm{RM} 2,00$. Hence, the investor may collect the profit from the value of price difference with the returned margin which is $R M 2,000+R 1,250=R M 3,250$. In this sense, the seller will suffer financial losses.

Nonetheless, if the situation occurs in contrary, which is the decrease of price to RM20.80, the investors will leave out the margin and it will be delivered to the contract seller that turn to be as a mortgage during the earlier agreement. The impact will show that the seller will gain profit from the loss of the investors (buyers). Obaidullah (2001) explained that this situation indicates that the loss shouldered by one side or party is a profit for the other side and this happens vice versa, if it is not involving any investment activity. Ergo, the role of margin payment is set to become a gambling money in this transaction activity.

\section{Conclusion}

The SSFs contract is one of the conventional financial instruments that exists from the massive development in the world of financial engineering. Objectively, this contract may return benefit and convenience for the individuals or institutions in the context of underlying stock movement management risk through the activity of securing the value which seems acceptable in the aspect of maqasid al-shariah, particularly in the context of hifz al-mal. However, the usage of derivative contract such as this future trading contract has arising few of shariah issues in practicing this transaction, based on the discussed contract. The impact shows that there is disagreement between scholars on the shariah permissibility of this contract. Henceforth, there are efforts from the scholars to put guidelines of shariah parameter in protecting the Islamic finance in order to ensure that this contract is secured within the ambit of Islamic shariah. Although there are scholars that agreeing on the status of this contract able to meet the principles of shariah on the aspect of Islamic finance structure of contract, this contract is still exposed to few of shariah issues such as the on the aspect of speculation and gambling. Thus, the efforts to establish guidelines of comprehensive and shariahcompliance contract implementation needs cooperation, high understanding and honesty of the market participants before joining any SSFs contract.

\section{Acknowlegement}

The authors acknowledge the financial support from Ministry of Higher Education Malaysia (MOHE) (RAGS/1/2014/SS07/UNISZA//1).

\section{Corresponding Author}

Mahmud Jamaludin, Faculty of Islamic Contemporary Studies, Universiti Sultan Zainal Abidin, Terengganu Darul Iman, Malaysia. Email: Aktivis2020@yahoo.com.my

\section{References}

Al-Amine, M. (2008), Risk Management In Islamic Finance; An Analysis of Derivatives Instruments in Commodity Markets, Boston: Brill's Arab and Islamic Law Series. 
INTERNATIONAL JOURNAL OF ACADEMIC RESEARCH IN BUSINESS AND SOCIAL SCIENCES

Vol. 10, No. 5, May, 2020, E-ISSN: 2222-6990 @ 2020 HRMARS

Al-Darir. (1993), Al-Gharar fi al-'Uqud wa Atharuhu fi al-Tatbiqat al-Mu'asirah. Jeddah: al-Ma'had alIslami li al-Buhus wa al-Tadrib al-Bank al-Islami li al-Tanmih.

Al-Khafif, Ali. (1996), Ahkam al-Muamalat al-Shar'iyyah. Kaherah: Dar al-Fikr al-'Arabi

Al-Masri, Yunus, R. (2007), "Speculation between Proponents and Opponents", Islamic Econ, Jil. 20, Bil. 1, h. 43-52.

Al-Saati, A. R. (2002), "Shariah Compatible Futures", JKAU: Islamic Econ, Jil. 15, h.3-25.

Al-Saati, A. R. (2003), The Permissible Gharar (Risk) in Calassical Islamic Jurisprudence, J.KAU: Islamic Econ, Jil. 16, Bil. 2.

Al-Zuhayli. (1997), al-Figh al-Islami wa Adillatuh. Beirut: Dar al-Fikr.

Bakar, M. D. (1998), Pasaran Hadapan Komoditi Minyak Sawit Mentah: Perspektif Syariah" (Kertas Kerja Seminar Pakar Syariah di Pan Pacific Legacy, Melaka, 30 Oktober 1998).

Bakar, M. D. (2008), "Hedging Contracts in Islamic Finance" (Kertas kerja $7^{\text {th }}$ conference of the Shariah Boards of Islamic Financial Institutions The Accounting and Auditing Organization for Islamic Financial Institutions (AAOIFI), Bahrain, 24-27 Mei 2008).

Chapra, M. U. (1988), "Towards an Islamic Financial System", Journal of Islamic Economics, Jil. 1, Bil. 2, Julai 1988, h. 1-30.

Ali, E. R. (2010), Produk berstruktur Islam", dalam Prosiding Muzakarah Penasihat Syariah Kewangan Islam, Kuala Lumpur Islamic Finance Forum 2008-2009, Kuala Lumpur: CERT Publication.

Haron, M. S. (2001), Jurnal Pengajian Umum Bil.2, Universiti Kebangsaan Malaysia (UKM), bil. 2, h.2729.

Hull, J. C. (2003), Options, Futures \& Other Derivatives. New Jersey; Pearson/Prentice Hall.

Al-Jawziyah, Ibn Q., Abi Bakr, M. Ibn. (1993), I'lam al-Muwaqqi'in 'An Rabb al-'Alamin. Beirut: Dar alKutub al-'Ilmiyyah.

Jaafar, A. B. (2014), Lindung Nilai Pasaran Niaga Hadapan Komoditi berasaskan Kontrak Bay' Salam, Jurnal Muamalat JAKIM, bil. 7, hlm. 181-195.

Kamali, M. H. (2002), Islamic Commercial Law: An Analysis of Futures and Options, Ilmiah Publisher; Kuala Lumpur.

Khan, M. A. (2008), "Commodity Exchange and Stock Exchange in an Islamic Economy”, dalam Sheikh Ghazali Sheikh Abod et. al., An Introduction to Islamic Economics \& Finance. Kuala Lumpur: CERT Publications Sdn. Bhd., h. 391-394.

Khan, M. F. (1995), Islamic Futures and Their markets: With Special References to their Role in Developing Rural Financial Market. Jeddah: Islamic Research and Training Institute, Islamic Development Bank.

Khan, M. F. (1997), "Islamic Futures Market as Means for Mobilizing Resources for Development", dalam Ausaf Ahmad dan Tariqullah Khan (eds.), Islamic Financial Instruments for Public Sector Resource Mobilization. Jeddah: Islamic Development Bank Islamic Research and Training Institute.

Majlis Penasihat Syariah AAOIFI. (2010), al-Ma'yir al-Syar'iyyah 1431H-2010, Manama: AAOIFI, 2010, h. 298.

Razif, M. N. F. (2014), Konsep Lindung Nilai Menurut Perspektif Syariah: Analisis Terhadap Opsyen, Tesis PhD. Kuala Lumpur: Akademi Pengajian Islam Universiti Malaya.

Naughton, S., and Tony. (2000), "Religion Ethics and Stock Trading: The Case of an Islamic Equities Market", Journal Business Ethics, Jil. 23, h. 145-159. 
INTERNATIONAL JOURNAL OF ACADEMIC RESEARCH IN BUSINESS AND SOCIAL SCIENCES

Vol. 10, No. 5, May, 2020, E-ISSN: 2222-6990 ㄷ 2020 HRMARS

Nordin, N. (2014), Gharar dalam kontrak derivatif Komoditi, Kuala Terengganu; Universiti Sultan Zainal Abidin.

Obaidullah, M. (1998), Financial Engineering with Islamic Options", Islamic Economics Studies, Jil. 6, Bil. 1, November 1998, h. 73-103.

Obaidullah, M. (2000), "What Shariah Experts Say: Currency Exchange" International Journal of Islamic Financial Services, Jil.2 Bil. 2, Julai-Sep 2000.

Obaidullah, M. (2001), "Ethics and Efficiency in Islamic Stock Market", International Journal of Islamic Financial Service, Jil.3, Bil. 2, Julai-Sept.

Ramli, S. (2000), Pasaran Niaga Hadapan: Melindung Nilai dan Spekulasi. Kuala Lumpur: Utusan Publications \& Distributors Sdn. Bhd.

Resolusi Akademi Fikah Islam (1992), Majallat Majma' al-Fiqh al-Islami, Jeddah: Majma' al-Fiqh alIslami, 1/7, h. 716.

Sang, C. Y. (2019), Manager, Institutional Development Bursa Malaysia Derivatives, Temubual atas talian pada 28 November 2019.

Sekuriti, S. (2005), Malaysian Futures and Options: examination study guide, Modul 2: Futures, Kuala Lumpur.

Sekuriti, S. (2006), Buku Keputusan Majlis Penasihat Syariah Suruhanjaya Sekuriti, Edisi Kedua, Kuala Lumpur.

Sekuriti, S. (2018), Buku Keputusan Majlis Penasihat Syariah Suruhanjaya Sekuriti Malaysia, 31 Disember 2018.

Syathnawi. (2009), Al-Athar al-Iqtisodiyah Li Aswaq al-Awraq al-Maliyah Min Manzhuri al-lqtisadi alIslamiy, Dar al-Nafaais; Jordan.

Tahir, H. M., \& Ahmad, S. (2009), Aplikasi Fiqh Muamalat dalam Sistem Kewangan Islam, Pusat Penerbitan Universiti (UPENA)

Usmani, M. T. (1999), "What Shariah Experts Say", International Journal of Islamic Financial Services, Jil. 1 Bil 1., April - Jun 1999, h. 1-3 